\title{
Contents, Vol. 27, Supplementum 1, 1970
}

\section{Index}

Introduction - Einleitung 291

Meeting on Disodium Cromoglycate (IntaliLomudal®) Chairman: Prof. R. Preisig, Berne

Cox, J. S. G. and Altounyan, R. E. C. (Leicestershire): Nature and Modes of

Action of Disodium Cromoglycate (Lomudal ${ }^{\circledR}$ ) $\quad 292$

Wüthrich, B. (Zurich): Erfahrungen mit Dinatrium cromoglicicum (Lomudal ${ }^{\circledR}$ )

in der Behandlung des Asthma bronchiale, insbesondere des Pollenasthmas

(Results with DSCG (Lomudal ${ }^{\circledR}$ ) in Treatment of Bronchial Asthma, Especially

of Pollen Asthma) 310

Bürgi, H. (Heiligenschwendi): Behandlung von Asthma bronchiale und chronischer asthmoider

Bronchitis mit Dinatrium cromoglicicum

(Treatment of Bronchial Asthma and Chronic Asthmoid Bronchitis with Di

sodium Cromoglycate) 322

Scherrer, M. and Wyss, F. (Berne): Response of Asthmatics on Three Weeks Intal

Treatment 326

Haller, R. de und Melliger, E. (Davos-Dorf): Die Wirkung von Dinatrium cromoglicicum

(Lomudal ${ }^{\circledR}$ ) beim erwachsenen Asthmatiker (Effects of Disodium Cromoglycate (Lomudal ${ }^{\circledR}$ )

in Adult Asthmatics) .... 341

Gartmann, J. (Arosa): Wirkung von DSCG und Bronchoskopiebefund

(Disodium Cromoglycate and Bronchoscopic Results) 349

Godfrey, S. (London): The Physiological Assessment of the Effect of DSCG in the

Asthmatic Child 353

Engström, Inga (Stockholm): Inhibition of the Bronchial Reaction Induced by

Allergen Inhalation in Children

Zuidema, P.; Cramer, M. A. und Lagally-RöIП·, I. (Davos-Platz): Untersuchung über Dinatrium cromoglicicum (Lomudal ${ }^{\circledR}$ )

(Investigations on Disodium Cromoglycate (Lomudal ${ }^{\circledR}$ ) 358

Streumer, J. (Molenheide): Treatment of Asthma with DSCG in Juveniles During and After Hospitalization 363

Marcelle, R. (Liège): Activité du DSCG sur la bronchomotricité de Thomme in vitro

(Activity of DSCG on the Human Bronchial in vitro) 